Review

\title{
Multiple Myeloma: What Do We Do About Immunodeficiency?
}

\author{
Linrong $\mathrm{Li}^{1}$, Liang Wang ${ }^{2}$ \\ 1. Second Clinical Medical College, Southern Medical University, Guangzhou, China. \\ 2. Department of Hematology, ZhuJiang Hospital of Southern Medical University, Guangzhou, China. \\ $\triangle$ Corresponding author: Liang Wang, M.D., Department of Hematology, ZhuJiang Hospital of Southern Medical University, Guangzhou, China. E-mail: \\ wangliangzjyy@126.com. Tel: +8615013009093 \\ (C) Ivyspring International Publisher. This is an open access article distributed under the terms of the Creative Commons Attribution (CC BY-NC) license \\ (https://creativecommons.org/licenses/by-nc/4.0/). See http://ivyspring.com/terms for full terms and conditions.
}

Received: 2018.09.17; Accepted: 2019.01.30; Published: 2019.04.03

\begin{abstract}
Multiple myeloma (MM) is an incurable hematological malignancy. Immunodeficiency results in the incapability of immunity to eradicate both tumor cells and pathogens. Immunotherapies along with antibiotics and other anti-infectious agents are applied as substitutes for immunity in MM. Immunotherapies including monoclonal antibodies, immune checkpoints inhibitors, affinityenhanced $T$ cells, chimeric antigen receptor $T$ cells and dendritic cell vaccines are revolutionizing MM treatment. By suppressing the pro-inflammatory milieu and pathogens, prophylactic and therapeutic antibiotics represent anti-tumor and anti-infection properties. It is expected that deeper understanding of infection, immunity and tumor physio-pathologies in MM will accelerate the optimization of combined therapies, thus improving prognosis in MM.
\end{abstract}

Key words: immunodeficiency, multiple myeloma, immunotherapy, antibiotic

\section{Introduction}

Multiple myeloma (MM) is a heterogeneous malignancy developed with the accumulation of malignant plasma cells within bone marrow. Common complications of MM are infections, anemia, renal failure, hypercalcemia and osteolytic bony lesions. Median age of MM patients at diagnosis is 69 in the USA and 59 in China. Patients with MM are expecting better prognosis in more recent decades. With the introduction of proteasome inhibitors and immunomodulatory agents, MM median overall survival is now beyond 60 months.[1] Notwithstanding the improved early-term survival, MM remains an incurable disease. From precancerous monoclonal gammopathy of uncertain significance, active stage, to plateau stage, MM will eventually and inevitably progress into relapsing stage and drug resistant stage. Repeated infections, development of drug resistance and disease progression in MM are all closely associated with the acquisition of immunodeficiency. [2-5]

Immunodeficiency principally results in the incapability of immunity to eradicate tumor cells and pathogens. The duality of immunodeficiency in MM patients is essential in understanding the latent interactions between malignant cells, pathogenic microorganisms and the host immunity, especially provided that we are to develop promising drugs to achieve curative potential. This review outlines the mechanisms and up-to-date clinical applications of several therapeutic strategies targeting immunodeficiency. We focus primarily on immunotherapies, especially novel treatment options of monoclonal antibodies and chimeric antigen receptor $\mathrm{T}$ cells, and anti-infectious agents, as substitutes for immunity to eradicate pathogens and malignant cells, respectively. Note that because of the same immunodeficiency background infections and myeloma share, a successful treatment on one can bring prospect for the other, which is demonstrated markedly in vaccines and antibiotics for MM.

\section{Immunodeficiency in MM}

The dysfunctional replication of plasma cells, 
chemotherapy-induced granulocytopenia and the high-dose administration of dexamethasone are all responsible for immunodeficiency, which involves in tumor evasion from the immune response.[2,6-9] Both humoral immunity and cellular immunity are impaired in concordance with abnormities of B cell, $\mathrm{T}$ cell, dendritic cell (DC) and natural killer (NK) cell et al., in terms of quantity and function[2,10-16] It was demonstrated that serum $\beta$-2-microglobulin was significantly higher in the MM subgroup with a high ratio of CD4+ cells to CD8+ cells in peripheral blood than in the subgroup with a normal ratio $(\mathrm{P}<$ 0.05).[12] Indeed, MM with a dismal long-term survival was accompanied with less-proliferated cytotoxic T-cell clones, lower Th17 cells and higher T-regulatory cells (Tregs).[17] Besides, DC function could be inhibited by profound immune dysregulations of various immune agents including TGF- $\beta$, IL-10, IL-6, PGE2 within myeloma microenvironment. $[18,19]$ Abused activation of programmed cell death protein-1 (PD-1) and cytotoxic T-lymphocyte associated protein 4 (CTLA-4) immune checkpoints also caused undesirable immunodeficiency in MM.[20,21] B7-H1 expression was upregulated on tumor cells, thus inducing T-cell suppression, tumor progression and drug resistance.[22,23] As for CTLA-4, it has been discovered in a polish cohort of 580 people that CTLA-4 gene polymorphism is relevant to susceptibility to MM. The frequency of CTLA-4c.49A>G[G] allele was much higher in the MM patients than in the controls ( $p=0.03, \mathrm{OR}=1.31, \mathrm{CI}=1.03-1.68)$.[24] CTLA-4 polymorphisms also have influence on outcomes of treatments involving bortezomib, the mechanism of which still waits to be fully elucidated.[25]

In abridged, we enumerate major immunodeficiency mechanisms in MM of recorded clinical significance: (1) abnormal expression of specific antigens on malignant cells;(2) enhanced expression of immune checkpoint inhibitory ligands by plasma cells;(3) T-cell abnormities;(4) dendritic cell dysfunctions;(5) immune microenvironment dysfunctions. Congruently, several therapeutic strategies targeting immunodeficiency are later addressed.

\section{Immunotherapy}

The fundamental basis for immunotherapy is to ameliorate the impaired immunity in $\mathrm{MM}$ through simulation or immune supplement. Apart from Arkansas total therapy protocols,[26] allogeneic stem cell transplantation (allo-SCT) is generally believed to be the only curative therapy for MM, despite the fact that high treatment-related mortality limits its use. $[17,27,28]$ Notion that MM regresses by immune enhancement strongly justifies the application of immunotherapy.[29] In accordance with the immunodeficiency mechanisms, various treatments are subsequently elucidated to address this dilemma: (1) monoclonal antibodies (mAbs);(2) immune checkpoints inhibitors;(3) affinity-enhanced $\mathrm{T}$ cell therapies and chimeric antigen receptor $\mathrm{T}$ cell therapies;(4) DC vaccines; (5) immunomodulatory drugs.

\section{Monoclonal Antibody}

The monoclonal antibodies (mAbs) are among the most promising therapies for patients with hematological or solid malignancies.[30] mAbs take advantage of the unique immunoglobulin expression by malignant cells. They specifically target functional surface antigens or immune agents, leading to different mechanisms that keep tumor at bay. The key step toward monoclonal antibody treatment is to identify suitable surface antigens. Ideally, a target for $\mathrm{mAb}$ therapy should be exclusively or predominantly expressed on most MM cells or other target cells in order to minimize substantial on-target off-tissue toxicity and maximize efficacy.

MAbs have shown encouraging ability to overcome $\mathrm{MM}$ resistance after traditional therapies. [31] Intriguingly, the anti-CD38 mAb daratumumab and anti-CS1 mAb elotuzumab were approved by FDA as breakthrough drugs for the treatment of MM in 2015. [32,33] Daratumumab (HuMax-CD38, Gen$\mathrm{mab}$ ) is a human IgG1к mAb that binds to the CD38 epitope on MM cells.[34] Main anti-myeloma mechanisms of daratumumab exhibited in preclinical studies include antibody-dependent cellular cytotoxicity (ADCC), omplement-dependent cytotoxicity (CDC), antibody-dependent cellular phagocytosis (ADCP) and cross- linking apoptosis.[35,36] In CASTOR phase 3 Trial (NCT02136134), the addition of daratumumab to the regimen of bortezomib and dexamethasone resulted in a significantly higher rate of 12-month progression-free survival $(60.7 \%$ vs. $26.9 \%)$, as was the rate of overall response $(82.9 \%$ vs. 63.2\%, $\mathrm{P}<0.001$ ).[37] In another phase 3 trial POLLUX (NCT02076009), the addition of daratumumab to the regimen of lenalidomide and dexamethasone demonstrated a significantly higher rate of overall response among patients with relapsed or refractory $\mathrm{MM}$ (92.9\% vs. 76.4\%, $\mathrm{P}<0.001)$. [38] Another mAb target, CS1, a member of the CD2 subset of immunoglobulin superfamily,[39] was expressed on NK cells and in more than $97 \%$ of MM patients.[40] The first-in-class humanized IgG1 anti-CS1 mAb, elotuzumab, was demonstrated to mediate ADCC, inhibit CS1mediated MM cell adhesion and directly enhance NK cell cytotoxicity in the bone marrow milieu.[40,41] A combination of $\mathrm{mAb}$ elotuzumab, lenalidomide and dexamethasone was reported to induce an 
over-12-month progression-free survival in 68\% patients with relapsed or refractory MM, as compared to $57 \%$ in patients who received only lenalidomide and dexamethasone. As for 24-month progression free survival, the rates were $41 \%$ and $27 \%$, respectively. Incidence of infusion reaction was $10 \%$, with 29 of 33 patients under grade 2.[42] Some of the most promising antigens and monoclonal antibodies for MM along with their mechanisms and clinical applications are described in this review. (see Table 1)

\section{Immune Checkpoint Inhibitor}

Immune checkpoints refer to an immune regulatory system which plays a crucial role in tumor immune evasion. CTLA-4 and PD- 1 are both immune checkpoint receptors on $\mathrm{T}$ cells. The engagement by their cognate ligands B7-1 (CD80)/ B7-2 (CD86) or programmed cell death ligand-1 (PD-L1)/ programmed cell death ligand-1 (PD-L2) on antigen-presenting cells leads to a temporary attenuation of T-cell activation.[43-45] Comparisons of the immune checkpoints CTLA-4 and PD-1 are generalized in Table 2.

Thus far, a subset of immune checkpoint inhibitors has been approved for therapeutic use in certain solid tumors by FDA and CFDA (China Food and Drug Administration). However, whether they have the same effect in patients with MM is not yet clear. As MM is a genetically and immunologically complex disease, it is possible that targeting only one immune checkpoint pathway will not be sufficient. [44] Low expression of PD-1 and CTLA-4, minimal numbers of infiltrating $\mathrm{T}$ cells and a relatively modest mutational burden are probably relevant to patients' suboptimal response to checkpoint inhibitors in MM compared with solid tumors.[46-48] The objective response rate of pembrolizumab, pomalidomide and dexamethasone was $50 \%$ in 24 patients with relapsed or refractory MM (NCT02289222).[49] What's more, a phase III randomized trial of pembrolizumab (MK3475), lenalidomide and dexamethasone is ongoing involving 640 participants with newly diagnosed and treatment-naïve $\mathrm{MM}$ who are ineligible for autologous stem cell transplantation (ASCT) (NCT02579863). [50] In the same trial, adverse events grade 3 to 4 including hematologic toxicities, hyperglycemia and pneumonia were observed in $40 \%$ patients who received 28-day cycles of pembrolizumab and dexamethasone.[51] The combination of pidilizumab and lenalidomide has demonstrated acceptable safety results in 12 patients with relapsed or refractory MM.[52] Generally speaking, checkpoints inhibitors are enticing immunotherapies but unlikely to be a panacea across $\mathrm{MM}$, and much remains to be done in order to maximize their therapeutic potential. (see Table 1)

Table 1. Promising targets (antigens) for CARTs and monoclonal antibodies in multiple myeloma

\begin{tabular}{|c|c|c|c|c|c|}
\hline Surface antigens & Monoclonal antibodies/ligands & Relevant agents and pathways & $\begin{array}{l}\text { Preclinical } \\
\text { CARTs }\end{array}$ & $\begin{array}{l}\text { Clinical } \\
\text { CARTs }\end{array}$ & References \\
\hline CD19 & - & - & YES & YES & {$[104,105]$} \\
\hline CD20 & rituximab, ibritumomab, tositumomab & PAX5/BSAP & - & - & {$[106,107]$} \\
\hline CD38 & daratumumab, SAR650984, MOR202 & CDC, ADCC, ADCP, apoptosis & YES & - & {$[32-36,38,108,109]$} \\
\hline CD40 & $\begin{array}{l}\text { G28-5, lucatumumab (HCD122), dacetuzumab } \\
\text { (SGN-40), 5C11, }\end{array}$ & IL-6, TNF, PI3K / AKT, VEGF & - & - & [110-113] \\
\hline CD44 (serglycin proteoglycan) & ARH460-16-2 & IL-6, serglycin, IGF-1 & YES & - & [114-117] \\
\hline CD54 (ICAM-1) & BI-505, TP15-FC & Mac-1, LFA-1 & - & - & [118-121] \\
\hline CD56 (NCAM-1, Leu-19) & HuN901, lorvatuzumab mertansine (IMGN901) & several cytokines & YES & - & {$[122,123]$} \\
\hline CD74 & milatuzumab (hLL1), IMMU-110 & HLA-DR, NF-кB, IL-8 & - & - & [124-127] \\
\hline CD81 & - & $\begin{array}{l}\text { PERK, IRE1, X-box binding } \\
\text { protein-1 }\end{array}$ & - & - & [128] \\
\hline CD138 (syndecan-1) & B-B4, ВТ062, 4B3 & NF-kB, STAT3, Dll1/Notch & YES & YES & [129-135] \\
\hline CD200 (MOX1, OX-2, MRC) & samalizumab, ALXN6000 & $\beta 2$ microglobulin, IGF-1R, ERK & - & - & {$[136,137]$} \\
\hline CD221 (IGF-1R) & IGF-1 (natural), AVE1642, linsitinib (OSI-906) & tyrosine kinase & - & - & [138] \\
\hline BCMA (CD269, TNFRSF17) & EM801, GSK2857916 & $\begin{array}{l}\text { BAFF (TNFSF13B), APRIL } \\
\text { (TNFSF13) }\end{array}$ & YES & YES & {$[58,139-144]$} \\
\hline CD274 (PD-L1, B7-H1) & MSB0010718C, atezolizumab, MEDI4716 & PD-1 & - & - & {$[46,145-148]$} \\
\hline CD317 (HM1-24, BST2) & GFTKO-AHM & ADCC & - & - & [149] \\
\hline CD319 (SLAMF-7, CS1, 19A24) & elotuzumab (HuLuc63, empliciti) & ADCC, CS1 & YES & - & {$[32,39-41]$} \\
\hline IL-6 & siltuximab & Ras, IL-6 & - & - & {$[150-152]$} \\
\hline RANKL & denosumab & $\begin{array}{l}\text { Serum C-terminal telopeptide of } \\
\text { type } 1 \text { collagen }\end{array}$ & - & - & {$[153]$} \\
\hline Dickkopf-1 (DKK1) & BHQ880 & IL-6, Wnt signaling & - & - & [154-156] \\
\hline PD-1 (CD279) & $\begin{array}{l}\text { nivolumab (MDX-1106), pembrolizumab } \\
\text { (MK-3475), pidilizumab (CT-011) }\end{array}$ & PD-L1 & YES & YES & {$[47,157-163]$} \\
\hline \multicolumn{6}{|c|}{$\begin{array}{l}\text { CARTs: chimeric antigen receptor T cells; CD: cluster of differentiation; ICAM-1: intercellular cell adhesion molecule-1; NCAM-1: neural cell adhesion molecule-1; IGF-1R: } \\
\text { insulin-like growth factor-1 receptor; BCMA: B cell maturation antigen; PD-L1: programmed cell death ligand-1; B7-H1: B7 homolog-1; SLAMF-7: signaling lymphocytic } \\
\text { activation molecule family member-7; IL: interleukin; RANKL: receptor activator of nuclear factor-kB ligand; PD-1: programmed cell death protein-1; IGF-1: insulin-like } \\
\text { growth factor-1; CDC: complement-dependent cytotoxicity; ADCC: antibody-dependent cellular cytotoxicity; ADCP: antibody-dependent cellular phagocytosis; TNF: tumor } \\
\text { necrosis factor; HLA: human lymphocyte antigen; STAT3: signal transducers and activators of transcription-3; ERK: extracellular regulated protein kinase; BAFF: B-cell } \\
\text { activating factor. }\end{array}$} \\
\hline
\end{tabular}


Table 2. Comparison of CTLA-4 and PD-1 receptors

\begin{tabular}{|c|c|c|}
\hline receptor & CTLA-4 & PD-1 \\
\hline ligands & B7-1/B7-2 & PD-L1/PD-L2 \\
\hline mechanism & competitive inhibition of CD28 costimulatory pathway & CD28 signaling regulation \\
\hline expression on Tregs & highly expressed & dispensable \\
\hline involved immune phase & priming phase of $\mathrm{T}$ cell activation & chronic antigenic stimulation \\
\hline other pathways & - & BCR signaling inhibition by recruiting SHP-2 \\
\hline clinical application in MM & - & in combined therapy \\
\hline other clinical applications & gastrointestinal, genitourinary cancers, melanoma & broad \\
\hline
\end{tabular}

\section{T-cell Therapy}

T-cell therapies fall into two major categories: non-gene-modified strategies and gene-modified strategies, or affinity-enhanced and chimeric antigen receptor $\mathrm{T}$ cell therapies. Those therapies rely on affinity-enhanced T-cell receptors (TCRs) or chimeric antigen receptors (CARs) to recognize specific antigens.

\section{Affinity-enhanced T-cell Therapy}

Observations that affinity-enhanced $\mathrm{T}$ cells are more likely to be found close to tumor lay a basis for affinity-enhanced T-cell therapies. By selection and expansion of marrow-infiltrating or genetically engineered $\mathrm{T}$ cells, the functional avidity between TCRs and tumor antigens was enhanced.[53] Unlike chimeric antigen receptor $\mathrm{T}$ cell therapies (CARTs), affinityenhanced therapies are human leucocyte antigen (HLA)-dependent and highly potentiated to recognize intracellular peptides. Nevertheless, affinity-enhanced therapies may result in HLA downregulation and deleterious off-target effects.[54, 55]

In NCT01245673, 27 patients with active and/or high-risk MM received the subcutaneous injection of MAGE-A3 Trojan peptide vaccine, poly-ICLC along with granulocyte macrophage colony-stimulating factor (GM-CSF) before ASCT. They had steady-state apheresis to have $\mathrm{T}$ cells collected 10 days after the injection. These $\mathrm{T}$ cells were depleted of monocytes, expanded, harvested and infused back to patients. High frequencies of immune responses were observed in patients.[56]

\section{Chimeric Antigen Receptor T-cell Therapy}

CARs are genetically engineered receptor- or ligand-based proteins exhibiting high, HLA-independent specificity and tumor cytotoxicity. A chimeric antigen receptor normally consists of an extracellular single-chain variable fragment derived from $\mathrm{mAbs}$ or a domain derived from native receptors, a spacer region, a transmembrane domain, a tyrosine-based activation domain (usually CD3 $\zeta$ ) ( $1^{\text {st }}$ generation), and one ( $2^{\text {st }}$ generation) or two (3 $3^{\text {st }}$ generation) intracellular costimulatory domains (e.g., CD28, OX40, ICOS or CD137).[57]
CARTs are the second step in T-cell engineering and there are currently satisfying early-stage clinical results in MM. Several targets have been under exploration, with B cell maturation antigen (BCMA) CARTs among the most promising.[58, 59] BCMA CARTs were both efficient and safe in heavily pre-treated relapsed or refractory $\mathrm{MM}$ according to a latest report of 16 patients. The rate of eradication of extensive bone and soft-tissue myeloma was $81 \%$, very good partial response or complete response $63 \%$, with severe but reversible toxicities.[60] However, one roadblock in the development of CARTs could be the lack of ideal targets. Ideally, targets for CART should be expressed on the surface of all MM cells but no normal tissues in most MM patients in order to avoid on-target off-tissue toxicity and maximize effectiveness.[61] Clinical and preclinical applications of the most promising CARTs targeting BCMA, CD19, CD38, CD138 et al. are listed in Table 1.

\section{Vaccine}

Vaccines in MM share anti-pathogen as well as direct anti-tumor potency. In the CAPiTA randomized double-blind clinical trial of 84,496 participants of age 65 years and older in the Netherlands (NCT00744263), the 13-valent pneumococcal conjugate vaccine efficacy of $45.56 \%$ was demonstrated for the first episode vaccine-type pneumococcal community-acquired pneumonia. Vaccination could also assist in the prevention of common etiologies for recurrent infections in MM patients, such as influenza, varicella, meningitis.[62] Simultaneously, vaccines became attractive in the field of cancer immunotherapy. Although mAbs have demonstrated potency in targeting malignant cells in $\mathrm{MM}$, the absence of immune memory limits the durability of remissions, under the circumstances of which we are anticipating a broader application in vaccines as immunotherapies. Nevertheless, a significant drawback of ordinary anti-tumor vaccines is their efficacy instability.[63] As already emphasized, this is partially because antigen presenting cells, in particular DCs, upon which costimulatory molecules are expressed to ensure satisfactory immune response, are insufficient both in number and function.[64] In order to circumvent this problem, the 
application of DC vaccines and several immune adjuvants is suggested.[65]

One research revealed that human dickkopf-1 and human heat shock protein-70 fusion vaccine could effectively elicit tumor apoptosis and prolonged survival in murine MM.[66] With regard to DC vaccines, evaluated antigen loading strategies include peptide based vaccines, genetically engineered antigen, viral/fungal vectors expressing cancer antigens and malignant cell apoptotic bodies,[67] while antigens of interest include mucin-1 (MUC1), New York-esophageal squamous cell carcinoma (NY-ESO1), melanoma antigen family (MAGE)-A3, MAGE-C1, and receptor for hyaluronan-mediated motility receptor (RHAMM). $[68,69]$ In a phase II clinical study, idiotype immunoglobulin-loaded DC vaccines were administered to patients intradermally. As a consequence, lower incidence of cumulative progression was observed 12 months after the first vaccination $(\mathrm{p}=$ 0.099).[70]

\section{Immunomodulatory Drug}

Immunomodulatory drugs (IMiDs) (i.e., thalidomide (a-N-phthalimido-glutarimide), lenalidomide (CC-5013), and pomalidomide (CC-4047)) are analogues with a multitude of direct and indirect antimyeloma effects, including potent anti-angiogenesis, ADCC, immune modulatory and anti-inflammatory properties.[71,72] A leading mechanism of IMiDs in $\mathrm{MM}$ is the degradation of essential lymphoid transcription factors IKZF1and IKZF3 by the CRBN-CRL4 ubiquitin ligase.[73] In combination with dexamethasone or proteasome inhibitors, IMiDs represents a paradigm shift in the treatment of MM and are currently used as frontline therapy.[74] In year 2006, both in combination with dexamethasone, lenalidomide was approved for relapsed or refractory $\mathrm{MM}$ and thalidomide was approved for newly diagnosed MM by FDA. The FDA approval for pomalidomide in relapsed or refractory $M M$ as a third line therapy was not issued until year 2013.[75] IMiDs are all contraindicated in pregnancy owing to proven teratogenic effects (e.g., phocomelia).[76] Other common side effects of IMiDs include fatigue, myelosuppression, peripheral neuropathy and thrombosis.[77]

\section{Antibiotics and Anti-viral Treatment}

\section{Infection and Anti-infective Treatment}

A direct consequence of immunodeficiency is the high risk of infection. The incidence rate of infectious episodes in MM was about 10 times higher than other hospitalized patients and responsible for $62.5 \%$ of early mortality in elderly patients with MM.[78,79] The infectious and re-infectious rate was $17.9 \%$ and
$41.9 \%$ in 260 hospitalized patients. Risk factors of infection for those patients were female, DurieSalmon stage IIIB, elevated serum creatinine, neutropenia, poor general condition and catheter indwelling.[80] 58\% of $\mathrm{MM}$ patients developed respiratory infections following allo-SCT in the first 12 months after diagnosis.[81]

In this context, preemptive administration of antibiotics has been somehow widely applied in MM. Daily administration of acyclovir, valacyclovir or famciclovir proved to be effective in preventing herpes zoster virus in MM patients treated with bortezomib.[82] For ASCT recipients, prophylactic levofloxacin led to a $27 \%$ decrease in blood stream infection as well as a $31 \%$ decrease in fever and neutropenia.[83] However, the clinical significance of prophylactic antibiotic was limited due to increasing emergence of resistant strains, toxicity, drug interactions and suspected antagonistic effects. As such, antibiotics should only be prescribed on "highinfection-rate circumstances" such as induction therapy, progression or refractoriness.[84] What's more, previous data only suggest the validity of early prophylactic antibiotic use (about 2 months within the induction therapy) in MM patients.[85,86] Additionally, the efficacy of prophylactic gamma globulin for $\mathrm{MM}$ was not verified and the reduction of the number of malignant cells was cited as a most effective way of improving host defense.[87]

\section{Infection and Tumor Progression}

The scenario that many patients with MM have severe bacterial infections shortly before or after diagnosis [88-90] and the significant role of certain viruses in MM pathogenesis reveal a link between infection and tumor progression.[91,92] Pathogenic microorganisms expressing pathogen-associated molecular patterns can trigger toll-like receptors on MM cells, accelerate $\mathrm{MM}$ cell growth and prevent chemotherapy-induced apoptosis. [93-95] What's more, by promoting the secretion of immune agents, infections can accelerate tumor progression. $[19,96,97]$ In this perspective, by promptly eradicating the pathogenic microorganisms and suppressing the pro-inflammatory immune milieu, antibiotics can theoretically represent both anti-tumor and antiinfection properties.

In fact, it was revealed in vitro in 2016 that the anti-infective chloramphenicol could induce MM cell apoptosis in a dose-relevant and time-dependent manner.[98] Simultaneously targeting two prominent intracellular protein degradation systems of the ubiquitin-proteasome system and the autophagylysosome system, macrolide antibiotics led to endoplasmic reticulum stress mediated and pro-apoptotic 
transcription factor CADD153 induced apoptosis in MM cell lines.[99] Besides, thalidomide and clarithromycin were discovered to synergistically downregulate TNF- $\alpha$ and IL-6 secretion probably via ERK1/2 and AKT inhibition.[100] As previously mentioned, antibiotics and other anti-infectious agents (i.e., vaccines, immunoglobulin, anti-viral drugs) have been successfully incorporated into MM regimens. Antibiotics suggest a synergistic action with other MM therapies. The combination of clarithromycin, low-dose thalidomide and dexamethasone (BLT-D) was of efficacy in patients with MM.[101] Another regimen of clarithromycin, lenalidomide, and dexamethasone (BiRD) also demonstrated effective in newly diagnosed MM.[102] Apart from antibiotics, for MM patients who underwent melphalan-based ASCT and developed ongoing parvovirus B19 infection, prophylactic intravenous immunoglobulin administration permitted prompt antineoplastic efficacy.[103]

\section{Conclusions and Future Directions}

Scientific progress is revolutionizing $\mathrm{MM}$ treatment, and development in immunotherapies as well as anti-infectious agents might thoroughly resolve the puzzle of immunodeficiency in near future. Promising immunotherapies involving mAbs, immune checkpoints inhibitors, therapeutic T-cells, vaccines/DC vaccines targeting specific immune mechanisms are currently under clinical and preclinical explorations. Rational combinations of immunotherapies, allo-SCT, chemotherapy, and antibiotics are ongoing to prolong progression-free survival with minimal toxicity. Further, some antibiotics such as clarithromycin and levofloxacin have been incorporated into MM treatment, and were of efficacy in prophylactic use.

Multiple myeloma is a most captivating example of "immune cancer", whereas in the authors' perspective, some immune signatures of MM still wait to be thoroughly described: (1) better targets in the mechanisms of immunodeficiency for MM diagnosis, prognosis, prophylaxis treatment and immunotherapies; (2) the precise correlation between peripheral immunity, microenvironment and tumor progression: is it adverse or favorable? Is it stage-related? What's the perfect timing for immunotherapies and antibiotics? (3) the distinct role of infection in different stages of $\mathrm{MM}$ and the clinical significance of prophylactic antibiotics.

Undoubtedly, combined therapies integrated with optimized modern clinical management will continue to deliver better anticipations for patients in years to come. With more biomarkers for pre-clinical and clinical myeloma to be defined, more emphasis will be laid on prophylaxis or early treatment and precision medicine. Hopefully, with collaborative efforts from oncologists, orthopedists, pathologists, pharmacologists, specialized nurses and the patients, the goal of MM treatment will eventually convert from "improving the length and quality of lives, achieving long-term disease-free survival", to ultimate cure of the disease.

\section{Abbreviations}

MM: Multiple myeloma; DC: dendritic cell; NK: natural killer; Tregs: T-regulatory cells; PD-1: programmed cell death protein-1; CTLA-4: cytotoxic T-lymphocyte associated protein 4; allo-SCT: allogeneic stem cell transplantation; mAbs: monoclonal antibodies; ADCC: antibody-dependent cellular cytotoxicity; CDC: complement-dependent cytotoxicity; ADCP: antibody-dependent cellular phagocytosis; PD-L1: programmed cell death-ligand-1; PD-L2: programmed cell death-ligand-2; ASCT: autologous stem cell transplantation; TCRs: T-cell receptors; CARs: chimeric antigen receptors; CARTs: chimeric antigen receptor $\mathrm{T}$ cell therapies; HLA: human leucocyte antigen; GM-CSF: granulocyte macrophage colony-stimulating factor; BCMA: B cell maturation antigen; IMiDs: Immunomodulatory drugs.

\section{Acknowledgements}

This work was supported by the National Natural Science Foundation of China [contract/grant number: 81873450 and 81400159$]$.

\section{Competing Interests}

The authors have declared that no competing interest exists.

\section{References}

1. Kumar SK, Callander NS, Alsina M, Atanackovic D, Biermann JS, Castillo J, Chandler JC, Costello C, Faiman M, Fung HC. NCCN Guidelines Insights: Multiple Myeloma, Version 3.2018. J Natl Compr Canc Netw. 2018; 16: 11-20.

2. Tamura H. Immunopathogenesis and immunotherapy of multiple myeloma. Int J Hematol. 2018; 107: 278-85.

3. Nikesitch N, Ling SC. Molecular mechanisms in multiple myeloma drug resistance. J Clin Pathol. 2015; 69: 97-101.

4. Jahangir A, Chen G, Hong C. Drug resistance in multiple myeloma: latest findings and new concepts on molecular mechanisms. Oncotarget. 2013; 4: 2186.

5. Gonzalez D, van der Burg M, Garcia-Sanz R, Fenton JA, Langerak AW, Gonzalez M, van Dongen JJM, San Miguel JF, Morgan GJ. Immunoglobulin gene rearrangements and the pathogenesis of multiple myeloma. Blood. 2007; 110: 3112-21.

6. Kiertscher SM, Luo J, Dubinett SM, Roth MD. Tumors promote altered maturation and early apoptosis of monocyte-derived dendritic cells. J Immunol. 2000; 164: 1269-76.

7. Greil R, Egle A, Villunger A. On the Role and Significance of Fas (Apo-1/CD95) Ligand (FasL) Expression in Immune Privileged Tissues and Cancer Cells Using Multiple Myeloma as a Model. Leuk Lymphoma. 1998; 31: 477-490.

8. Brown R, Murray A, Pope B, Sze DM, Gibson J, Ho PJ, Hart D, Joshua D. Either interleukin-12 or interferon- $\gamma$ can correct the dendritic cell defect induced by transforming growth factor $\beta 1$ in patients with myeloma. Br J Haematol. 2004; 125: 743-8.

9. Villunger A, Egle A, Marschitz I, Kos M, Böck G, Ludwig H, Geley S, Kofler R, Greil R. Constitutive expression of Fas (Apo-1/CD95) ligand on multiple 
myeloma cells: a potential mechanism of tumor-induced suppression of immune surveillance. Blood. 1997; 90: 12-20.

10. Yoneda K, Morii T, Nieda M, Tsukaguchi N, Amano I, Tanaka H, Yagi H, Narita N, Kimura H. The peripheral blood Va24+NKT cell numbers decrease in patients with haematopoietic malignancy. Leuk Res. 2005; 29: 147-52.

11. Koike M, Sekigawa I, Okada M, Matsumoto M, Iida N, Hashimoto H, Oshimi K. Relationship between CD4+/CD8+ $\mathrm{T}$ cell ratio and $\mathrm{T}$ cell activation in multiple myeloma: reference to IL-16. Leuk Res. 2002; 26: 705-11.

12. Ogawara $H$, Handa $H$, Yamazaki $T$, Toda $T$, Yoshida $K$, Nishimoto $N$, Al-ma'Quol WHS, Kaneko Y, Matsushima T, Tsukamoto N, Nojima Y, Matsumoto M, Sawamura M, et al. High Th1/Th2 ratio in patients with multiple myeloma. Leuk Res. 2005; 29: 135-40.

13. Macgregor RR, Negendank WG, Schreiber AD. Impaired granulocyte adherence in multiple myeloma: relationship to complement system, granulocyte delivery, and infection. Blood. 1978; 51: 591-9.

14. Mills KHG, Cawley JC. Abnormal monoclonal antibody-defined helper/suppressor T-cell subpopulations in multiple myeloma: relationship to treatment and clinical stage. Br J Haematol. 1983; 53: 271-5.

15. Rawstron AC, Davies FE, Owen RG, English A, Pratt G, Child JA, Jack AS, Morgan GJ. B-lymphocyte suppression in multiple myeloma is a reversible phenomenon specific to normal B-cell progenitors and plasma cell precursors. Br J Haematol. 1998; 100: 176-83.

16. Hájek R, Butch AW. Dendritic cell biology and the application of dendritic cells to immunotherapy of multiple myeloma. Med Oncol. 2000; 17: 2-15.

17. Kuruvilla J, Shepherd JD, Sutherland HJ, Nevill TJ, Nitta J, Le A, Forrest DL, Hogge DE, Lavoie JC, Nantel SH. Long-term outcome of myeloablative allogeneic stem cell transplantation for multiple myeloma. Biol Blood Marrow Transpl. 2007; 13: 925-31.

18. Pratt G, Goodyear O, Moss P. Immunodeficiency and immunotherapy in multiple myeloma. Br J Haematol. 2007; 138: 563-79.

19. Merico F, Bergui L, Gregoretti MG, Ghia P, Aimo G, Lindley IJD, Caligaris-Cappio F. Cytokines involved in the progression of multiple myeloma. Clin Exp Immunol. 1993; 92: 27-31.

20. Paiva B, Azpilikueta A, Puig N, Ocio EM, Sharma R, Oyajobi BO, Labiano S, Sansegundo L, Rodriguez A, Airesmejia I. PD-L1/PD-1 presence in the tumor microenvironment and activity of PD-1 blockade in multiple myeloma. Leukemia. 2015; 29: 2110-3.

21. Braga WMT, Vettore AL, Carvalho AC, Atanackovic D, Colleoni GWB. Overexpression of CTLA-4 in the Bone Marrow of Patients with Multiple Myeloma As a Sign of Local Accumulation of Immunosuppressive Tregs Perspectives for Novel Treatment Strategies. Blood. 2011; 118: 1829

22. Tamura H, Ishibashi M, Yamashita T, Tanosaki S, Okuyama N, Kondo A, Hyodo H, Shinya E, Takahashi H, Dong H, Tamada K, Chen L, Dan K, et al. Marrow stromal cells induce B7-H1 expression on myeloma cells, generating aggressive characteristics in multiple myeloma. Leukemia. 2013; 27: 464-72.

23. Ray A, Das DS, Song Y, Richardson P, Munshi NC, Chauhan D, Anderson KC. Targeting PD1-PDL1 immune checkpoint in plasmacytoid dendritic cells interactions with $\mathrm{T}$ cells, natural killer cells, and multiple myeloma cells. Leukemia. 2015; 29: 1441-4.

24. Karabon L, Pawlak-Adamska E, Tomkiewicz A, Jedynak A, Kielbinski M, Woszczyk D, Potoczek S, Jonkisz A, Kuliczkowski K, Frydecka I. Variations in Suppressor Molecule CTLA-4 Gene Are Related to Susceptibility to Multiple Myeloma in a Polish Population. Pathol Oncol Res. 2012; 18: 219-26.

25. Qin X-Y, Lu J, Li G-X, Wen L, Liu Y, Xu L-P, Chang Y-J, Liu K-Y, Jiang Z-F, Huang X-J. CTLA-4 polymorphisms are associated with treatment outcomes of patients with multiple myeloma receiving bortezomib-based regimens. Ann Hematol. 2018; 97: 485-95.

26. Nair B, Van RF, Jr SJ, Anaissie E, Szymonifka J, Hoering A, Alsayed Y, Waheed S, Crowley J, Barlogie B. Superior results of Total Therapy 3 (2003-33) in gene expression profiling-defined low-risk multiple myeloma confirmed in subsequent trial 2006-66 with VRD maintenance. Blood. 2010; 115: 4168-73.

27. Crawley C, Iacobelli S, Björkstrand B, Apperley JF, Niederwieser D, Gahrton G. Reduced-intensity conditioning for myeloma: lower nonrelapse mortality but higher relapse rates compared with myeloablative conditioning. Blood. 2007; 109: 3588-94.

28. Bensinger WI. Is there still a role for allogeneic stem-cell transplantation in multiple myeloma? Best Pract Res Clin Haematol. 2007; 20: 783-95.

29. Le Blanc R, Montminy-Métivier S, Bélanger R, Busque L, Fish D, Roy D-C, Kassis J, Boileau J, Lavallée R, Bélanger D, Letendre F, Hébert J, Sauvageau G, et al. Allogeneic transplantation for multiple myeloma: further evidence for a GVHD-associated graft-versus-myeloma effect. Bone Marrow Transplant. 2001; 28: 841-8.

30. Scott AM, Wolchok JD, Old LJ. Antibody therapy of cancer. Nat Rev Cancer. 2012; 12: 278-87.

31. Richardson PG, Lonial S, Jakubowiak AJ, Harousseau J-L, Anderson KC. Monoclonal antibodies in the treatment of multiple myeloma: Review. $\mathrm{Br} \mathrm{J}$ Haematol. 2011; 154: 745-54

32. Laubach JP, Paba Prada CE, Richardson PG, Longo DL. Daratumumab, Elotuzumab, and the Development of Therapeutic Monoclonal Antibodies in Multiple Myeloma. Clin Pharmacol Ther. 2017; 101: 81-8.

33. Bhatnagar V, Gormley NJ, Luo L, Shen YL, Sridhara R, Subramaniam S, Shen G, Ma L, Shord S, Goldberg KB, Farrell AT, McKee AE, Pazdur R. FDA Approval Summary: Daratumumab for Treatment of Multiple Myeloma After One Prior Therapy. The Oncologist. 2017; 22: 1347-53.
34. Lokhorst HM, Plesner $\mathrm{T}$, Laubach JP, Nahi $\mathrm{H}$, Gimsing $\mathrm{P}$, Hansson $\mathrm{M}$, Minnema MC, Lassen U, Krejcik J, Palumbo A. Targeting CD38 with Daratumumab Monotherapy in Multiple Myeloma. N Engl J Med. 2015; 373: 1207-19.

35. Jensen JHM, Boross P, Overdijk MB, Lammerts van Bueren JJ, Parren PWHI, Leusen JHW. Daratumumab, a human CD38 antibody induces apoptosis of myeloma tumor cells via Fc receptor-medicated crosslinking.(abstract 2974). Atlanta, GA, USA; 2012

36. de Weers M, Tai Y-T, van der Veer MS, Bakker JM, Vink T, Jacobs DCH, Oomen LA, Peipp M, Valerius T, Slootstra JW, Mutis T, Bleeker WK, Anderson $\mathrm{KC}$, et al. Daratumumab, a novel therapeutic human CD38 monoclonal antibody, induces killing of multiple myeloma and other hematological tumors. J Immunol. 2011; 186: 1840-8.

37. Palumbo A, Chanankhan A, Weisel K, Nooka AK, Masszi T, Beksac M, Spicka I, Hungria V, Munder M, Mateos MV. Daratumumab, Bortezomib, and Dexamethasone for Multiple Myeloma. N Engl J Med. 2016; 375: 754

38. Dimopoulos MA, Oriol A, Nahi H, San-Miguel J, Bahlis NJ, Usmani SZ, Rabin N, Orlowski RZ, Komarnicki M, Suzuki K, Plesner T, Yoon S-S, Ben Yehuda D, et al. Daratumumab, Lenalidomide, and Dexamethasone for Multiple Myeloma. N Engl J Med. 2016; 375: 1319-31.

39. Kumaresan PR, Lai WC, Chuang SS, Bennett M, Mathew PA. CS1, a novel member of the CD2 family, is homophilic and regulates NK cell function. Mol Immunol. 2002; 39: 1-8.

40. Tai Y-T, Dillon M, Song W, Leiba M, Li X-F, Burger P, Lee AI, Podar K, Hideshima T, Rice AG, van Abbema A, Jesaitis L, Caras I, et al. Anti-CS1 humanized monoclonal antibody HuLuc63 inhibits myeloma cell adhesion and induces antibody-dependent cellular cytotoxicity in the bone marrow milieu. Blood 2008: 112: 1329-37.

41. Collins SM, Bakan CE, Swartzel GD, Hofmeister CC, Efebera YA, Kwon H, Starling GC, Ciarlariello D, Bhaskar S, Briercheck EL, Hughes T, Yu J, Rice A, et al. Elotuzumab directly enhances NK cell cytotoxicity against myeloma via CS1 ligation: evidence for augmented NK cell function complementing ADCC. Cancer Immunol Immunother. 2013; 62: 1841-9.

42. Lonial S, Dimopoulos M, Palumbo A, White D, Grosicki S, Spicka I, Waltercroneck A, Moreau P, Mateos MV, Magen H. Elotuzumab Therapy for Relapsed or Refractory Multiple Myeloma. N Engl J Med. 2015; 373: 621-31.

43. Armand P. Immune checkpoint blockade in hematologic malignancies. Blood. 2015 May 28;125(22):3393-400.

44. Rosenblatt J, Avigan D. Targeting the PD-1/PD-L1 axis in multiple myeloma: a dream or a reality? Blood. 2017; 129: 275-9.

45. Walker LSK. PD-1 and CTLA-4: Two checkpoints, one pathway? Sci Immunol. 2017; 2(11): eaan3864.

46. Rosenblatt J, Avigan D. Targeting the PD-1/PD-L1 axis in multiple myeloma: a dream or a reality? Blood. 2017; 129: 275-9.

47. Suen $\mathrm{H}$, Brown R, Yang S, Ho PJ, Gibson J, Joshua D. The failure of immune checkpoint blockade in multiple myeloma with PD-1 inhibitors in a phase 1 study. Leukemia. 2015; 29: 1621-2.

48. Suen H, Brown R, Yang S, Weatherburn C, Ho PJ, Woodland N, Nassif N, Barbaro P, Bryant C, Hart D, Gibson J, Joshua D. Multiple myeloma causes clonal T-cell immunosenescence: identification of potential novel targets for promoting tumour immunity and implications for checkpoint blockade. Leukemia. 2016; 30: 1716-24.

49. Ashraf Z. Badros, Mehmet H. Kocoglu, Ning Ma, Aaron P. Rapoport, Emily Lederer, Sunita Philip, Patricia Lesho, Cameron Dell, Nancy M. Hardy, Jean Yared, Olga Goloubeva and Zeba Singh. A Phase II Study of Anti PD-1 Antibody Pembrolizumab, Pomalidomide and Dexamethasone in Patients with Relapsed/Refractory Multiple Myeloma (RRMM). Blood. 2015; 126(23): 506.

50. Palumbo A, Mateos M, Miguel JS, Shah J, Thompson S, Marinello P, Jagannath S. Pembrolizumab in combination with lenalidomide and low-dose dexamethasone in newly diagnosed and treatment-naive multiple myeloma (MM): randomized, phase 3 KEYNOTE-185 study. Ann Oncol. 2016; 27(suppl_6)

51. Badros A, Hyjek E, Ma N, Lesokhin A, Dogan A, Rapoport AP, Kocoglu M, Lederer E, Philip S, Milliron T. Pembrolizumab, pomalidomide and low dose dexamethasone for relapsed/refractory multiple myeloma. Blood. 2017; 130: 1189

52. Efebera YA, Rosko AE, Hofmeister C, Benner J, Bakan C, Stamper K, Lamb T, Hollie D, Sell M, Avigan D. First interim results of a phase I/II study of lenalidomide in combination with anti-PD-1 monoclonal antibody MDV9300 (CT-011) in patients with relapsed/refractory multiple myeloma. Blood. 2015; 126.

53. Danhof S, Hudecek M, Smith EL. CARs and other T cell therapies for MM: The clinical experience. Best Pract Res Clin Haematol. 2018; 31: 147-57.

54. Morgan RA, Chinnasamy N, Abate-Daga D, Gros A, Robbins PF, Zheng Z, Dudley ME, Feldman SA, Yang JC, Sherry RM. Cancer regression and neurological toxicity following anti-MAGE-A3 TCR gene therapy. J Immunother. 2013; 36: 133-51.

55. Dudley ME, Rosenberg SA. Adoptive-cell-transfer therapy for the treatment of patients with cancer. Nat Rev Cancer. 2003; 3: 666.

56. Rapoport AP, Aqui NA, Stadtmauer EA, Vogl DT, Xu YY, Kalos M, Cai L, Fang H-B, Weiss BM, Badros A, Yanovich S, Akpek G, Tsao P, et al. Combination Immunotherapy after ASCT for Multiple Myeloma Using MAGE-A3/Poly-ICLC Immunizations Followed by Adoptive Transfer of 
Vaccine-Primed and Costimulated Autologous T Cells. Clin Cancer Res. 2014; 20: $1355-65$.

57. Murad JM, Graber DJ, Sentman CL. Advances in the use of natural receptor- or ligand-based chimeric antigen receptors (CARs) in haematologic malignancies. Best Pract Res Clin Haematol. 2018; 31: 176-83.

58. Bu DX, Singh R, Choi EE, Ruella M, Nunezcruz S, Mansfield KG, Bennett P, Barton N, Wu Q, Zhang J. Pre-clinical validation of B cell maturation antigen (BCMA) as a target for $\mathrm{T}$ cell immunotherapy of multiple myeloma. Oncotarget. 2018; 9(40): 25764-80.

59. Cohen AD. CAR T Cells and Other Cellular Therapies for Multiple Myeloma: 2018 Update. Am Soc Clin Oncol Educ Book. 2018; 38: e6-15.

60. Brudno JN, Maric I, Hartman SD, Rose JJ, Wang M, Lam N, Stetler-Stevenson M, Salem D, Yuan C, Pavletic S, Kanakry JA, Ali SA, Mikkilineni L, et al. T Cells Genetically Modified to Express an Anti-B-Cell Maturation Antigen Chimeric Antigen Receptor Cause Remissions of Poor-Prognosis Relapsed Multiple Myeloma. J Clin Oncol. 2018; 36: 2267-80.

61. Linette GP, Stadtmauer EA, Maus MV, Rapoport AP, Levine BL, Emery L, Litzky L, Bagg A, Carreno BM, Cimino PJ, Binder-Scholl GK, Smethurst DP, Gerry $\mathrm{AB}$, et al. Cardiovascular toxicity and titin cross-reactivity of affinity-enhanced T cells in myeloma and melanoma. Blood. 2013; 122: 863-71.

62. Alemu A, Richards JO, Oaks MK, Thompson MA. Vaccination in Multiple Myeloma: Review of Current Literature. Clin Lymphoma Myeloma Leuk. 2016; 16: 495-502.

63. Bladé J, Rosiñol L. Renal, hematologic and infectious complications in multiple myeloma. Best Pract Res Clin Haematol. 2005; 18: 635-52.

64. Hájek R, Butch AW. Dendritic cell biology and the application of dendritic cells to immunotherapy of multiple myeloma. Med Oncol. 2000; 17: 2-15.

65. Bae J, Smith R, Daley J, Mimura N, Tai YT, Anderson KC, Munshi NC. Myeloma-Specific Multiple Peptides Able to Generate Cytotoxic T Lymphocytes: A Potential Therapeutic Application in Multiple Myeloma and Other Plasma Cell Disorders. Clin Cancer Res. 2012; 18: 4850-60.

66. Liu TT, Wu Y, Niu T. Human DKK1 and human HSP70 fusion DNA vaccine induces an effective anti-tumor efficacy in murine multiple myeloma. Oncotarget. 2018; 9: 178-91.

67. Pyzer AR, Avigan DE, Rosenblatt J. Clinical trials of dendritic cell-based cancer vaccines in hematologic malignancies. Hum Vaccines Immunother. 2014; 10: 3125-31.

68. Luptakova K, Avigan D. Immune therapy in multiple myeloma. Clin Adv Hematol Oncol. 2015; 13: 767-75

69. Taylor-Papadimitriou J, Burchell JM, Graham R, Beatson R. Latest developments in MUC1 immunotherapy. Biochem Soc Trans. 2018; 46: 659-68.

70. Zahradova L, Mollova K, Ocadlikova D, Kovarova L, Adam Z, Krejci M, Pour L, Krivanova A, Sandecka V, Hajek R. Efficacy and safety of Id-protein-loaded dendritic cell vaccine in patients with multiple myeloma - Phase II study results. Neoplasma. 2012: 59:440-9.

71. Quach H, Ritchie D, Stewart AK, Neeson P, Harrison S, Smyth MJ, Prince HM. Mechanism of action of immunomodulatory drugs (IMiDS) in multiple myeloma. Leukemia. 2010; 24: 22-32.

72. Sedlarikova L, Kubiczkova L, Sevcikova S, Hajek R. Mechanism of immunomodulatory drugs in multiple myeloma. Leuk Res. 2012; 36: 1218-24.

73. Kronke J, Udeshi ND, Narla A, Grauman P, Hurst SN, McConkey M, Svinkina T, Heckl D, Comer E, Li X, Ciarlo C, Hartman E, Munshi N, et al. Lenalidomide Causes Selective Degradation of IKZF1 and IKZF3 in Multiple Myeloma Cells. Science. 2014; 343: 301-5.

74. Stewart AK, Richardson PG, San-Miguel JF. How I treat multiple myeloma in younger patients. Blood. 2009; 114: 5436-43.

75. Holstein SA, McCarthy PL. Immunomodulatory Drugs in Multiple Myeloma: Mechanisms of Action and Clinical Experience. Drugs. 2017; 77: 505-20.

76. Raje N, Anderson K. Thalidomide--a revival story. N Engl J Med. 1999; 341: 1606-9.

77. Bianchi G, Anderson KC. Understanding biology to tackle the disease: Multiple myeloma from bench to bedside, and back: Clinical Aspects and Biology of Myeloma. CA Cancer J Clin. 2014; 64: 422-44.

78. Bladé J, Rosiñol L. Complications of Multiple Myeloma. Hematol Oncol Clin North Am. 2007; 21: 1231-46.

79. Xia J, Wang L, Zhou X, Wang J, Wang H, Guo H. Early mortality in elderly patients undergoing treatment for multiple myeloma in real-world practice. J Int Med Res. 2018; 46: 2230-7.

80. Valkovic T, Gacic V, Ivandic J, Petrov B, Dintinjana RD, Hero ED, Duletic AN. Infections in Hospitalised Patients with Multiple Myeloma: Main Characteristics and Risk Factors. Turk J Hematol. 2015; 32: 234-42.

81. Lavi N, Avivi I, Kra-Oz Z, Oren I, Hardak E. Community-acquired respiratory infections are common in patients with non-Hodgkin lymphoma and multiple myeloma. Support Care Cancer. 2018; 26: 2425-31.

82. Vickrey E, Allen S, Mehta J, Singhal S. Acyclovir to prevent reactivation of varicella zoster virus (herpes zoster) in multiple myeloma patients receiving bortezomib therapy. Cancer. 2015; 115: 229-32.

83. Satlin MJ, Vardhana S, Soave R, Shore TB, Mark TM, Jacobs SE, Walsh TJ, Gergis U. Impact of Prophylactic Levofloxacin on Rates of Bloodstream Infection and Fever in Neutropenic Patients with Multiple Myeloma Undergoing Autologous Hematopoietic Stem Cell Transplantation. Biol Blood Marrow Transpl. 2015; 21: 1808-14.

84. Valkovic T, Nacinovic AD, Petranovic D. Prophylactic broad spectrum antibiotics as a new anti-myeloma therapy. Med Hypotheses. 2013; 81: 1137-40.
85. Terpos E. Multiple Myeloma: Clinical Updates From the American Society of Hematology Annual Meeting, 2017. Clin Lymphoma Myeloma Leuk. 2018; 18: 321-34.

86. Vesole DH, Heckler C, Greipp PR, Katz MS, Jacobus S, Morrow GR. Oral antibiotic prophylaxis of early infection in multiple myeloma: a URCC/ECOG randomized phase III study. Leukemia. 2012; 26: 2517-20.

87. Salmon SE, Samal BA, Hayes DM, Hosley H, Miller SP, Schilling A. Role of gamma globulin for immunoprophylaxis in multiple myeloma. N Engl J Med. 1967; 277: 1336-40

88. Tamura H. Immunopathogenesis and immunotherapy of multiple myeloma. Int J Hematol. 2018; 107: 278-85.

89. Landgren O, Rapkin JS, Mellemkjaer L, Gridley G, Goldin LR, Engels EA. Respiratory tract infections in the pathway to multiple myeloma: a population-based study in Scandinavia. Haematologica. 2006; 91: 1697-700.

90. Lindqvist E, R Goldin L, Landgren O, Blimark C, Mellqvist U, Turesson I, Wahlin A, Björkholm M, Kristinsson S. Personal and family history of immune-related conditions increase the risk of plasma cell disorders: A population-based study. Blood. 2011; 118: 6284-91.

91. Deo Y, Ghebremariam H, Cloyd M. Detection and characterization of murine ecotropic recombinant virus in myeloma and hybridoma cells. Hybridoma. 1994; 13: 69-76.

92. Sadeghian MH, Ayatollahi H, Keramati MR, Memar B, Jamedar SA, Avval MM, Sheikhi M, Shaghayegh G. The association of Epstein-Barr virus infection with multiple myeloma. Indian J Pathol Microbiol. 2012; 54: 720-4.

93. Bohnhorst J, Rasmussen T, Moen SH, Fløttum M, Knudsen L, Børset M, Espevik T, Sundan A. Toll-like receptors mediate proliferation and survival of multiple myeloma cells. Leukemia. 2006; 20: 1138-44.

94. Jego G, Bataille R, Geffroy-Luseau A, Descamps G, Pellat-Deceunynck C. Pathogen-associated molecular patterns are growth and survival factors for human myeloma cells through Toll-like receptors. Leukemia. 2006; 20: 1130-7.

95. Jiang T-W, Xiong H-M, Sheng J-H, Cui Y-H, Zhang H-X, Shen P, Zhong R-Q. Growth inhibition and apoptosis of a multiple myeloma cell line induced by TLR3 pathway activation. 2011; 31: 815-8.

96. Kovacs E. How does interleukin-6 affect the membrane expressions of interleukin-6 receptor and gp130 and the proliferation of the human myeloma cell line OPM-2? Biomed Pharmacother. 2003; 57: 489-94.

97. Dankbar B, Padró T, Leo R, Feldmann B, Kropff M, Mesters RM, Serve H, Berdel WE, Kienast J. Vascular endothelial growth factor and interleukin-6 in paracrine tumor-stromal cell interactions in multiple myeloma. Blood. 2000; 95: 2630.

98. Tian F, Wang C, Tang M , et al. The antibiotic chloramphenicol may be an effective new agent for inhibiting the growth of multiple myeloma[J]. Oncotarget. 2016; 7(32):51934-42.

99. Moriya S, Che X-F, Komatsu S, Abe A, Kawaguchi T, Gotoh A, Inazu M, Tomoda A, Miyazawa K. Macrolide antibiotics block autophagy flux and sensitize to bortezomib via endoplasmic reticulum stress-mediated $\mathrm{CHOP}$ induction in myeloma cells. Int J Oncol. 2013; 42: 1541-50.

100. Qiu XH, Shao JJ, Mei JG, Li HQ, Cao HQ. Clarithromycin Synergistically Enhances Thalidomide Cytotoxicity in Myeloma Cells. Acta Haematol. 2016; 135: 103.

101. Coleman M, Leonard J, Lyons L, Pekle K, Nahum K, Pearse R, Niesvizky R, Michaeli J. BLT-D (Clarithromycin [Biaxin], Low-Dose Thalidomide, and Dexamethasone) for the Treatment of Myeloma and Waldenström's Macroglobulinemia. Leuk Lymphoma. 2002; 43: 1777-82.

102. Niesvizky R, Jayabalan DS, Christos PJ, Furst JR, Naib T, Ely S, Jalbrzikowski J, Pearse RN, Zafar F, Pekle K, LaRow A, Lent R, Mark T, et al. BiRD (Biaxin [clarithromycin]/Revlimid [lenalidomide]/dexamethasone) combination therapy results in high complete- and overall-response rates in treatment-naive symptomatic multiple myeloma. Blood. 2008; 111: 1101-9.

103. Katragadda L, Shahid Z, Restrepo A, Muzaffar J, Alapat D, Anaissie E. Preemptive intravenous immunoglobulin allows safe and timely administration of antineoplastic therapies in patients with multiple myeloma and parvovirus B19 disease. Transpl Infect Dis Off J Transplant Soc. 2013; 15: 354-60.

104. Porter DL, Kalos M, Frey NV. Chimeric Antigen Receptor Modified T Cells Directed Against CD19 (CTL019 cells) Have Long-Term Persistence and Induce Durable Responses In Relapsed, Refractory CLL. Blood. 2013; 122: 4162-4162.

105. Garfall A L, Stadtmauer E A, Hwang W T, et al. Anti-CD19 CAR T cells with high-dose melphalan and autologous stem cell transplantation for refractory multiple myeloma. Jci Insight. 2018; 3: 8 .

106. Kapoor P, Greipp PT, Morice WG, Rajkumar SV, Witzig TE, Greipp PR. Anti-CD20 monoclonal antibody therapy in multiple myeloma. Br J Haematol. 2008; 141: 135-48.

107. Lin P, Mahdavy M, Zhan F, Zhang HZ, Katz RL, Shaughnessy JD. Expression of PAX5 in CD20-positive multiple myeloma assessed by immunohistochemistry and oligonucleotide microarray. Mod Pathol Off J U S Can Acad Pathol Inc. 2004; 17: 1217.

108. Palumbo A, Chanankhan A, Weisel K, Nooka AK, Masszi T, Beksac M, Spicka I, Hungria V, Munder M, Mateos MV. Daratumumab, Bortezomib, and Dexamethasone for Multiple Myeloma. N Engl J Med. 2016; 375: 754

109. Endell J, Boxhammer R, Wurzenberger C, Ness D, Steidl S. The Activity of MOR202, a Fully Human Anti-CD38 Antibody, Is Complemented by ADCP and Is Synergistically Enhanced by Lenalidomide in Vitro and in Vivo. Blood. 2012; 120: 4018. 
110. Bensinger W, Maziarz RT, Sundar Jagannath, Spencer A, Durrant S, Becker PS, Ewald B, Bilic S, Rediske J, Baeck J. A phase 1 study of lucatumumab, a fully human anti-CD40 antagonist monoclonal antibody administered intravenously to patients with relapsed or refractory multiple myeloma. Br J Haematol. 2012; 159: 58-66.

111. Westendorf JJ, Ahmann GJ, Armitage RJ, Spriggs MK, Lust JA, Greipp PR, Katzmann JA, Jelinek DF. CD40 expression in malignant plasma cells. Role in stimulation of autocrine IL-6 secretion by a human myeloma cell line. J Immunol. 1994; 152: 117.

112. Qi CJ, Zheng L, Zhou X, Tao Y, Ge Y, Zhuang YM, Xu Y, Yu G, Zhang XG. Cross-linking of CD40 using anti-CD40 antibody, 5C11, has different effects on XG2 multiple myeloma cells. Immunol Lett. 2004; 93: 151-8.

113. Hayashi T, Treon SP, Hideshima T, Tai YT, Akiyama M, Richardson P, Chauhan D, Grewal IS, Anderson KC. Recombinant humanized anti-CD40 monoclonal antibody triggers autologous antibody-dependent cell-mediated cytotoxicity against multiple myeloma cells. Br J Haematol. 2003; 121: 592-6.

114. Casucci M, Nicolis di RB, Falcone L, Camisa B, Norelli M, Genovese P, Gentner B, Gullotta F, Ponzoni M, Bernardi M. CD44v6-targeted T cells mediate potent antitumor effects against acute myeloid leukemia and multiple myeloma. Blood. 2013; 122: 3461-72.

115. Vincent T, Mechti N. IL-6 regulates CD44 cell surface expression on human myeloma cells. Leukemia. 2004; 18: 967-75.

116. Asosingh K, Günthert U, Bakkus MH, De RH, Goes E, Van RI, Van CB, Vanderkerken $\mathrm{K}$. In vivo induction of insulin-like growth factor-I receptor and CD44v6 confers homing and adhesion to murine multiple myeloma cells. Cancer Res. 2000; 60: 3096-104.

117. Purushothaman A, Toole BP. Serglycin Proteoglycan Is Required for Multiple Myeloma Cell Adhesion, in Vivo Growth, and Vascularization. J Biol Chem. 2014; 289: 5499 .

118. Klausz K, Cieker M, Kellner C, Oberg HH, Kabelitz D, Valerius T, Burger R, Gramatzki M, Peipp M. A novel Fc-engineered human ICAM-1/CD54 antibody with potent anti-myeloma activity developed by cellular panning of phage display libraries. Oncotarget. 2017; 8: 77552-66.

119. Klausz K, Cieker M, Burger R, Günther A, Kellner C, Peipp M, Gramatzki M. A novel human Fc-optimized ICAM-1/CD54 antibody (MSH-TP15e) with potent anti-myeloma activity in vitro and in vivo. Clin Lymphoma Myeloma Leuk. 2015; 15: 221-221.

120. S Diamond M, Staunton D, R de Fougerolles A, Stacker S, Garcia-Aguilar I, L Hibbs M, Springer T. ICAM-1 (CD54): a counter-receptor for Mac-1 (CD11b/CD18). 1991; 111.

121. Coleman EJ, Brooks KJ, Smallshaw JE, Vitetta ES. The Fc portion of UV3, an anti-CD54 monoclonal antibody, is critical for its antitumor activity in SCID mice with human multiple myeloma or lymphoma cell lines. J Immunother. 2006; 29: 489-98

122. Tassone P, Gozzini A, Goldmacher V, Shammas MA, Whiteman KR, Carrasco $\mathrm{DR}, \mathrm{Li}$ C, Allam CK, Venuta S, Anderson KC. In vitro and in vivo activity of the maytansinoid immunoconjugate huN901-N2'-deacetyl-N2'-(3-mercapto-1-oxopropyl)-maytansine against CD56+ multiple myeloma cells. Cancer Res. 2004; 64: 4629-36.

123. Benjamin R, Condomines M, Gunset G, Sadelain M. Abstract 3499: CD56 targeted chimeric antigen receptors for immunotherapy of multiple myeloma. Cancer Res. 2012; 72: 3499.

124. Basha G, Omilusik K, Chavezsteenbock A, Reinicke AT, Lack N, Choi KB, Jefferies WA. A CD74-dependent MHC class I endolysosomal cross-presentation pathway. Nat Immunol. 2012; 13: 237-45.

125. Sapra P, Stein R, Pickett J, Qu Z, Govindan SV, Cardillo TM, Hansen HJ, Horak ID, Griffiths GL, Goldenberg DM. Anti-CD74 antibody-doxorubicin conjugate, IMMU-110, in a human multiple myeloma xenograft and in monkeys. Clin Cancer Res Off J Am Assoc Cancer Res. 2005; 11: 5257-64.

126. Beswick EJ, Pinchuk IV, Minch K, Suarez G, Sierra JC, Yamaoka Y, Reyes VE. The Helicobacter pylori Urease B Subunit Binds to CD74 on Gastric Epithelial Cells and Induces NF-KB Activation and Interleukin-8 Production. Infect Immun. 2006; 74: 1148-55.

127. Kaufman JL, Niesvizky R, Stadtmauer EA, Chanankhan A, Siegel D, Horne H, Wegener WA, Goldenberg DM. Phase I, multicentre, dose-escalation trial of monotherapy with milatuzumab (humanized anti-CD74 monoclonal antibody) in relapsed or refractory multiple myeloma. Br J Haematol. 2013; 163: $478-86$

128. Zismanov $\mathrm{V}$, et al. Tetraspanin-induced death of myeloma cell lines is autophagic and involves increased UPR signalling. Br J Cancer. 2009; 101: 1402-9.

129. WanpingSun, FengmingWang, FangXie, GuogingWang JinSun, GehuaYu, YuhuaQiu, XueguangZhang. A novel anti-human syndecan-1 (CD138) monoclonal antibody 4B3: characterization and application. Cell Mol Immunol. 2007; 4: 209-214.

130. Jagannath S, Heffner T, Avigan D, Lutz R, Osterroth F, Ruehle M, Haeder T, Munshi N, Anderson KA. BT062, an Antibody-Drug Conjugate Directed against CD138, Shows Clinical Activity in a Phase I Study in Patients with Relapsed or Relapsed/Refractory Multiple Myeloma. Blood. 2011; 118: 305.

131. Tassone $P$. Cytotoxic activity of the maytansinoid immunoconjugate B-B4-DM1 against CD138+ multiple myeloma cells. Blood. 2004; 104: 3688-96.

132. Xu D, Hu J, Xu S, De BE, Menu E, Van CB, Vanderkerken $K$, Van VE. Dll1/Notch activation accelerates multiple myeloma disease development by promoting CD138+ MM-cell proliferation. Leukemia. 2012; 26: 1402-5.
133. Bae J, Tai Y T , Anderson K C , et al. Novel epitope evoking CD138 antigen-specific cytotoxic $\mathrm{T}$ lymphocytes targeting multiple myeloma and other plasma cell disorders. Br J Haematol. 2011; 155(5): 349-361.

134. Bharti AC. Nuclear factor- B and STAT3 are constitutively active in CD138+ cells derived from multiple myeloma patients, and suppression of these transcription factors leads to apoptosis. Blood. 2004; 103: 3175-84.

135. Bo G, Xia CM, Wang HQ, Hui F, Ren DH, Ying ZW, Jing ZY, Yao W, Li ZH, Dong HW. CD138-directed adoptive immunotherapy of Chimeric Antigen Receptor (CAR)-modified T cells for Multiple Myeloma. J Cell Immunother. 2016; 2 : 28-35.

136. Conticello C, Giuffrida R, Parrinello N, Buccheri S, Adamo L, Sciuto MR, Colarossi C, Aiello E, Chiarenza A, Romano A. CD200 expression in patients with Multiple Myeloma: Another piece of the puzzle. Leuk Res. 2013; 37: 1616-21.

137. Aref S, Azmy E, El-Gilany AH. Upregulation of CD200 is associated with regulatory $\mathrm{T}$ cell expansion and disease progression in multiple myeloma. Hematol Oncol, 2015. http://www.ncbi.nlm.nih.gov/ pubmed/26033514

138. Moreau P, et al. Phase I Study of AVE1642 Anti IGF-1R Monoclonal Antibody in Patients with Advanced Multiple Myeloma. Blood. 110: 1166.

139. Cohen $\mathrm{AD}$ et al. B-Cell Maturation Antigen (BCMA)-Specific Chimeric Antigen Receptor T Cells (CART-BCMA) for Multiple Myeloma (MM): Initial Safety and Efficacy from a Phase I Study. Blood. 2016; 128: 1147.

140. Carpenter RO, Evbuomwan MO, Pittaluga S, Rose JJ, Raffeld M, Yang S, Gress RE, Hakim FT, Kochenderfer JN. B-cell Maturation Antigen Is a Promising Target for Adoptive T-cell Therapy of Multiple Myeloma. Clin Cancer Res. 2013; 19: 2048-60.

141. Fan F, Zhao W, Liu J, He A, Chen Y, Cao X, Yang N, Wang B, Zhang P, Zhang $Y$. Durable remissions with BCMA-specific chimeric antigen receptor (CAR)-modified $\mathrm{T}$ cells in patients with refractory/relapsed multiple myeloma. J Clin Oncol. 2017; 35: LBA3001.

142. Seckinger A, Delgado JA, Moser S, Moreno L, Neuber B, Grab A, Lipp S, Merino J, Prosper F, Emde M. Target Expression, Generation, Preclinical Activity, and Pharmacokinetics of the BCMA-T Cell Bispecific Antibody EM801 for Multiple Myeloma Treatment. Cancer Cell. 2017; 31: 396.

143. Ali SA, Shi V, Maric I, Wang M, Stroncek DF, Rose JJ, Brudno JN, Stetler-Stevenson M, Feldman SA, Hansen BG. T cells expressing an anti-B-cell-maturation-antigen chimeric antigen receptor cause remissions of $\begin{array}{llll}\text { multiple } & \text { myeloma. } & \text { Blood. } & 2016 ;\end{array}$ http://www.ncbi.nlm.nih.gov/pubmed/27412889

144. Abramson HN. Monoclonal Antibodies for the Treatment of Multiple Myeloma: An Update. Int J Mol Sci. 2018; 19(12): 3924.

145. Armand P. Immune checkpoint blockade in hematologic malignancies. 2015; 125: 9 .

146. Tamura H, Ishibashi M, Yamashita T, Tanosaki S, Okuyama N, Kondo A, Hyodo H, Shinya E, Takahashi H, Dong H, Tamada K, Chen L, Dan K, et al. Marrow stromal cells induce B7-H1 expression on myeloma cells, generating aggressive characteristics in multiple myeloma. Leukemia. 2013; 27: 464-72

147. Hallett WHD, Jing W, Drobyski WR, Johnson BD. Immunosuppressive effects of Multiple Myeloma are overcome by PD-L1 blockade. Biol Blood Marrow Transplant. 2011; 17: 1133-1145.

148. Hargadon KM, Johnson CE, Williams CJ. Immune checkpoint blockade therapy for cancer: An overview of FDA-approved immune checkpoint inhibitors. Int Immunopharmacol. 2018; 62: 29-39.

149. Ishiguro $T$, Kawai $S$, Habu $K$, Sugimoto $M$, Shiraiwa $H$, Iijima $S$, Ozaki $S$, Matsumoto T, Yamada-Okabe H. A defucosylated anti-CD317 antibody exhibited enhanced antibody-dependent cellular cytotoxicity against primary myeloma cells in the presence of effectors from patients. 2010; 101(10): 2227-33.

150. Lun S, Shen B. The biological function of IL-6 on a human multiple myeloma cell-KM-3 is mediated by Ras/NF-IL-6 signal transduction pathway. Chin J Microbiol Immunol. 2000; http://europepmc.org/abstract/CBA/339915

151. Suzuki $K$, Ogura $M$, Abe $Y$, Suzuki $T$, Tobinai $K$, Ando $K$, Taniwaki $M$, Maruyama D, Kojima M, Kuroda J. Phase 1 study in Japan of siltuximab, an anti-IL-6 monoclonal antibody, in relapsed/refractory multiple myeloma. Int J Hematol. 2015; 101: 286-94.

152. Sanmiguel J, Bladé J, Shpilberg O, Grosicki S, Maloisel F, Min CK, Polo ZM, Robak T, Prasad SV, Tee GY. Phase 2 randomized study of bortezomib-melphalan-prednisone with or without siltuximab (anti-IL-6) in multiple myeloma. Blood. 2014; 123: 4136-42.

153. Vij R, Horvath N, Spencer A, Taylor K, Vadhan-Raj S, Vescio R, Smith J, Qian Y, Yeh H, Jun S. An Open-Label, Phase 2 Trial of Denosumab in the Treatment of Relapsed (R) or Plateau-Phase (PP) Multiple Myeloma (MM). Am J Hematol. 2010; 84: 650-6.

154. Liu TT, Wu Y, Niu T. Human DKK1 and human HSP70 fusion DNA vaccine induces an effective anti-tumor efficacy in murine multiple myeloma. Oncotarget. 2018; 9: 178-91.

155. Fulciniti M; Tassone P; Hideshima T; Vallet S; Nanjappa P; Ettenberg SA; Shen Z; Patel N; Tai YT; Chauhan D; Mitsiades C; Prabhala R; Raje N; Anderson KC; Stover DR; Munshi NC. Anti-DKK1 mAb (BHQ880) as a potential therapeutic agent for multiple myeloma. Blood. 2009; 114: 371-9.

156. Fulciniti M, Tassone $P$, Hideshima T, Vallet $S$, Nanjappa $P$, Ettenberg SA, Shen Z, Patel N, Tai YT, Chauhan D. Anti-DKK1, BHQ880, myeloma, Wnt inhibitor Dickkopf-1. Blood. 2009; 114: 371-9.

157. Ray A, Das DS, Song Y, Richardson P, Munshi NC, Chauhan D, Anderson KC. Targeting PD1-PDL1 immune checkpoint in plasmacytoid dendritic cells 
interactions with $\mathrm{T}$ cells, natural Killer cells, and multiple myeloma cells. Leukemia. 2015; 29: 1441-4.

158. Crescenzi A, Annibali O, Bianchi A, Pagano A, Donati M, Grifoni A, Avvisati G. PD-1/PD-L1 expression in extra-medullary lesions of multiple myeloma. Leuk Res. 2016; 49: 98-101.

159. Ashraf Z, et al. A Phase II Study of Anti PD-1 Antibody Pembrolizumab, Pomalidomide and Dexamethasone in Patients with Relapsed/Refractory Multiple Myeloma (RRMM). Blood. 126: 506.

160. Walker LSK. PD-1 and CTLA-4: Two checkpoints, one pathway? Sci Immunol. 2017; 2(11): eaan3864.

161. Curran MA, Montalvo W, Yagita H, Allison JP. PD-1 and CTLA-4 combination blockade expands infiltrating $\mathrm{T}$ cells and reduces regulatory $\mathrm{T}$ and myeloid cells within B16 melanoma tumors. Proc Natl Acad Sci U A. 2010; 107: 4275-80.

162. Ansell SM, Lesokhin AM, Borrello I, Halwani A, Scott EC, Gutierrez M, Schuster SJ, Millenson MM, Cattry D, Freeman GJ. PD-1 Blockade with Nivolumab in Relapsed or Refractory Hodgkin's Lymphoma. N Engl J Med. 2015; 372: 311

163. Lesokhin AM, Ansell SM, Armand P, Scott EC, Halwani A, Gutierrez M, Millenson MM, Cohen AD, Schuster SJ, Lebovic D. Preliminary Results of a Phase I Study of Nivolumab (BMS-936558) in Patients with Relapsed or Refractory Lymphoid Malignancies. Blood. 2014; 124: 291. 